\title{
Lし 論文＼cjkstart石炭中の鉱物質の粒度分布および単体分離性について*
}

一 物理的選別法による石炭の脱灰性に関する研究（第 2 報）-

$$
\text { 王楠 }{ }^{1} \text { 平島 剛 }{ }^{2} \text { 恒川昌 } \text { 美 }^{3}
$$

\author{
Size Distribution and Liberation of Mineral Matter in Coal \\ - Study on removal characteristics of mineral matter \\ from coal by physical separation ( 2 nd Report) - \\ by Nan WANG ${ }^{1}$, Tsuyoshi HIRAJIMA ${ }^{1}$ and Masami TSUNEKAWA ${ }^{1}$ \\ 1. Faculty of Engineering, Hokkaido University, Kita - ku, Sapporo 060
}

\begin{abstract}
Mineral matters in six coal samples from different localities were classified into four groups; A) mainly quartz, B) pyrite, C) mainly clay minerals and D) iron oxide. The size distribution and liberation degree of each group mineral were measured using an image analyzer equipped with a microscope. Minerals of A, B and D groups were easily liberated from coal by grinding. On the other hand, $C$ group minerals were easily crushed but often remained and attached to the coal particles. Based on the results measured and observed, a liberation model was proposed to evaluate the liberation behaviour of the minerals. Using the model, liberation degrees were calculated and the values agreed well with the measured values.
\end{abstract}

KEY WORDS : Liberation, Size Distribution of Mineral Matter, De - ashing of Coal, Advanced Coal Cleaning Technique

\section{1. 緒言}

著者らは, 先に比重選別で除去することが困難な鉱物は, 炭種に より異なることを報告した1。このことは, 石炭中に含まれている 鉱物の種類, 粒度分布, 分布状態, 単体分離性等が異なることによ るあのであり, 石炭の高度な脱灰・脱硫を行う上でこれらを適切に 把握することは, 極めて重要であると考えられる。従来, 主として 脱硫の観点から, 石炭中の黄鉄鉱の粒度分布等については, 多くの


分布や分布状態, 単体分離性等については, 測定例は少なく, 不明 な点が多い。

そこで, 本研究では, 顕微鏡付き画像解析装置を用い, 石炭試料 中の鉱物質を外観の性状により分類し, それらの同定を行うととも に粒度分布, 単体分離度を測定した。さらに, 各鉱物質の粒度分布 測定等の結果から得られた知見に基づき, 各鉱物質の硬度を考慮し た鉱物質単体分離モデルを提案し, 石炭の粉砕粒度と鉱物質の単体 分離度との関係について検討した。

\section{2. 石 炭試 料}

石炭試料は前報1) と同一であり, 大同炭（中国）, 太平洋炭（日 本), Illinois炭 (アメリカ), Wyoming 炭 (アメリカ), Battle River炭（カナダ）, Wandoan炭（オーストラリア）の代表試料

\footnotetext{
* 1993 年 9 月 28 日受付 12 月 8 日受理 資源・素材学会平成 3 年度春季大 会にて一部講演

1. 工博 北海道工業技術研究所（前 北海道大学大学院学生）

2. 正会員 工博 北海道大学助手 工学部資源開発工学科

3. 正会員 工博 北海道大学助教授 工学部資源開発工学科

キーワード：単体分離, 鉱物質粒度分布, 石炭の脱灰, 高度石炭精製技術
}

（粒度 $-850 \mu \mathrm{m}(-20 \mathrm{mesh})$, 以後 $-20 \mathrm{mesh}$ 試料之呼ぶ）を用いた。 大同炭, Illinois炭, Wandoan炭については, さらに乳鉢で $75 \mu \mathrm{m}$ (200mesh) 以下に乾式粉砕した試料（以後 -200 mesh 試料と呼ぶ） を実験に供した。

石炭試料中の鉱物質粒子および石炭粒子の粒度分布測定には, 以 下の方法で作成したブリケット（直径 $25 \mathrm{~mm}$ ）を使用した。

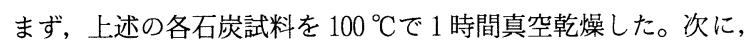
この試料とバインダーとを混合・加熱することにより作製した直径 $25 \mathrm{~mm}$ のブリケットの平坦な面を 240 番, 600 番の研磨紙で磨いた 後, 絹布上で順次 $5 \mu \mathrm{m}, 3 \mu \mathrm{m}, 1 \mu \mathrm{m}, 0.5 \mu \mathrm{m}$ のアルミナスラリー を用いて研磨した。このブリケットを石炭試料中の鉱物質粒子およ び石炭粒子の粒度分布測定に供した。バインダーとして熱硬化性ぺ トロポキシ 154 (米国パルース・ペトロ・プロダクッ社製）を使用 した。

\section{3. 実 験 方 法}

\section{$3 \cdot 1$ 石炭および鉱物質の粒度分布測定}

石炭試料中の鉱物質粒子および石炭粒子についての粒度分布測定 は, 反射型光学顕微鏡 (ニコン(株)XPF - $\mu \mathrm{NR}$ - II) 付き画像解 析装置（ニレコ(株)LUZEX II）を用いて, 以下の手順で行った。

まず, 十字線付き接眼レンズの十字線值下の石炭粒子または単体 分離している鉱物質粒子の円面積相当径の測定を行う。次に, 石炭 粒子の場合はその石炭粒子中に存在する鉱物質の円面積相当径の測 定を顕微鏡の倍率を適宜変化させながら行う。この測定が終了した 後, 試料台を水平方向に $0.5 \mathrm{~mm}$ 移動させ, 上記測定を繰り返す。 一水平方向の測定が終了したら, 試料台を垂直方向に $0.5 \mathrm{~mm}$ 移 動させ, 前とは逆の方向に同様に測定を行う。以後, この測定を繰 り返す。 

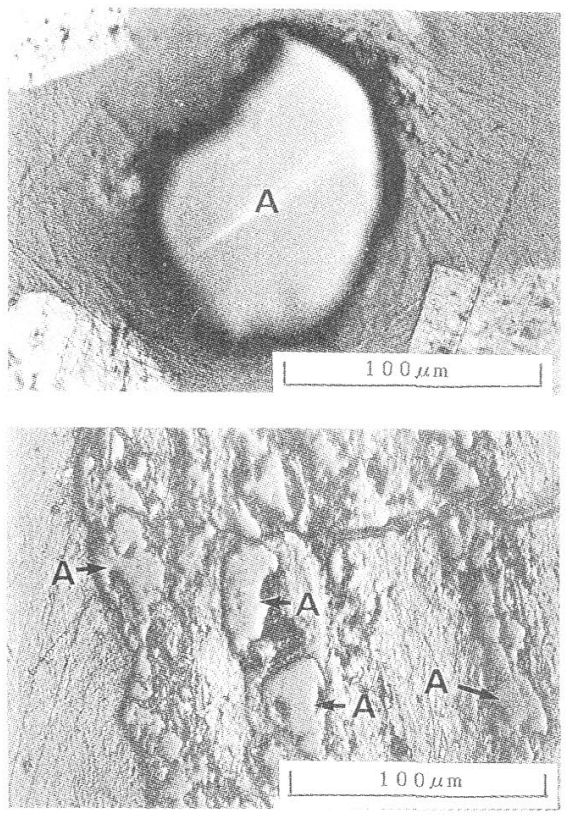

Fig. 1 Reflected light images of A group mineral.
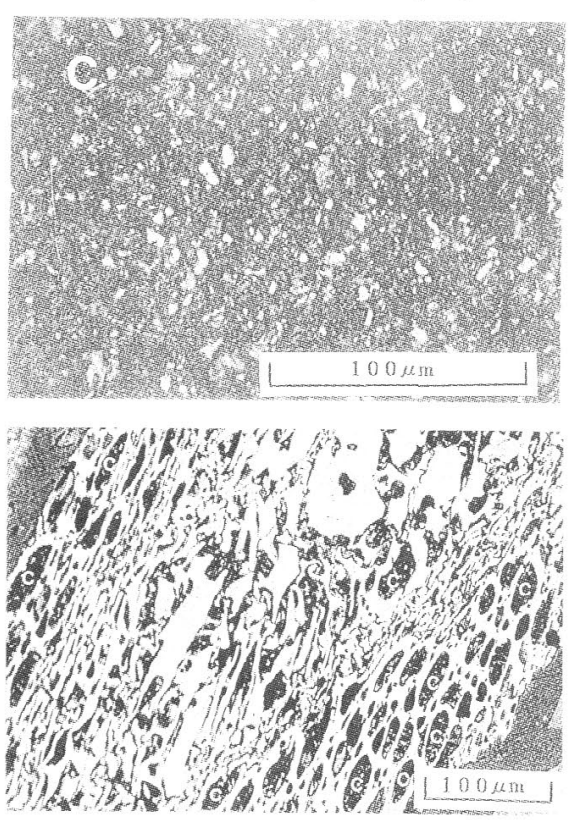

Fig. 3 Reflected light images of $\mathrm{C}$ group mineral.

\section{3 ・2 X線マイクロアナライザ $(\mathrm{XMA})$ による元素分析}

3・1 で使用したブリケットの表面に $\mathrm{Au}$ - Pd 合金を用いてコー ティングを行った後，エネルギー分散型分光計付き反射型走査電子 顕微鏡を用いて，元素分析を行った。コーティングは，電圧 1.2

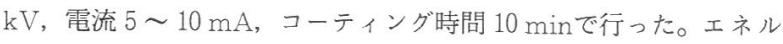
ギー分散型分光計は NINK 製の Q200J, 反射型走查電子顕微鏡は 日本電子製の JEOL JSM - 35CF I を使用した。また，加速電圧 は $20 \mathrm{kV}$ とした。

\section{4. 実験結果および考察}

\section{$4 \cdot 1$ 鉱物質グループ}

各石炭の-20mesh 試料について反射型光学顕微鏡で観察した結 果, 石炭試料中の鉱物質はそれぞれの外観の性状により次の四つの グループに分類できた。顕微鏡写真の一例を Fig. 1 4 亿示す。

Aグループ: 微細な透明あるいは半透明鉱物であり,これらは,
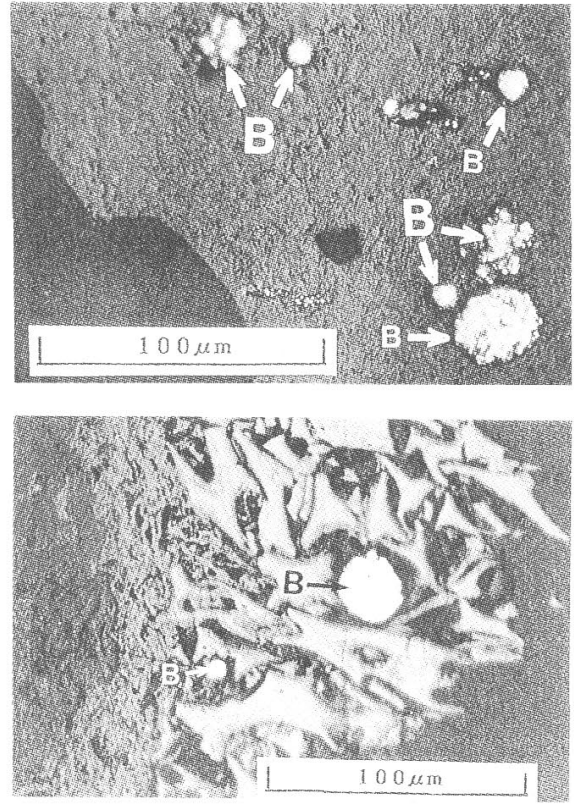

Fig. 2 Reflected light images of B group mineral.
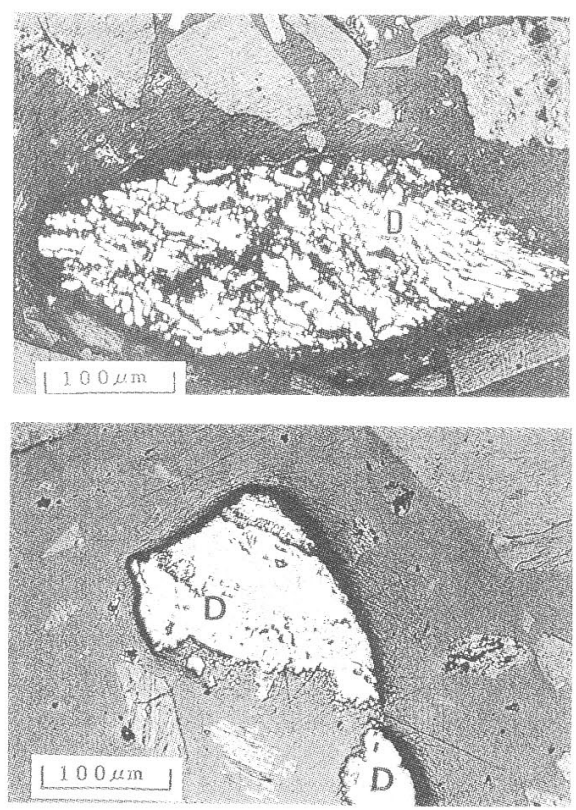

Fig. 4 Reflected light images of D group mineral.

研磨後, 石炭の表面より突起しており，石炭より硬い鉱物と思われ る (Fig. 1)。

Bグループ：明るい黄色の金属光沢を呈している鉱物であり，研 磨後, 石炭の表面より突起しており, 石炭より硬い鉣物と思われる (Fig. 2)。

Cグループ：褐色がかった微粒子の集合体および他のグループに 属していない不透明鉱物である（Fig. 3)。

Dグループ：明るい白色の金属光沢を呈している鉱物であり，研 磨後, 石炭の表面より突起しており,石炭より硬い鉱物と思われる (Fig. 4)。

A, Cグループの鉱物質はいずれの石炭中にも存在しているが, B グループの鉱物質は主に大同炭, Illinois 炭に存在していた。Dグ ループの鉱物質は主にWyoming 炭に存在しており, Wandoan 炭 にも少量確認された。Wandoan 炭の場合，Cグループの鉱物質の 量が多く, 他の石炭に存在するCグループの鉱物質に比べその粒度 


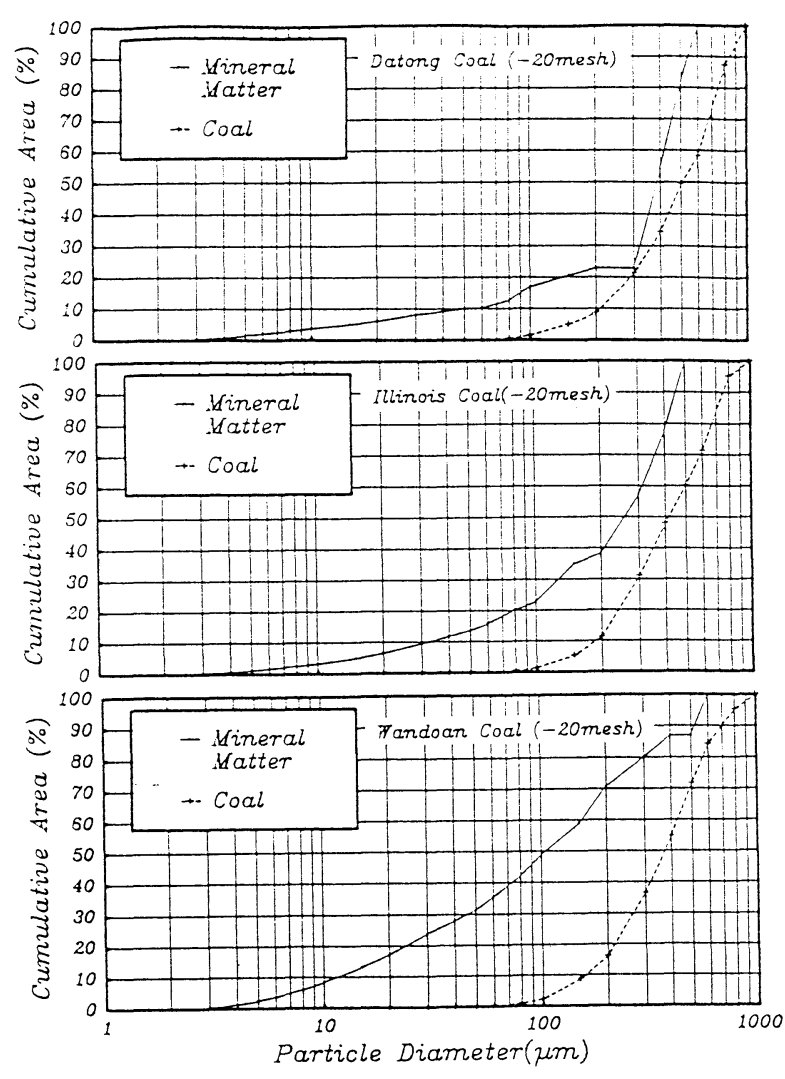

Fig. 5 Size distribution of coal and mineral matter in -20 mesh samples.

は小さかった。

A， B， C，Dグループにそれぞれ属する鉱物質の XMA によ る元素分析結果では, Aグループの鉱物質には珪素, Bグループの 鉱物質には鉄と硫黄, Cグループの鉱物質にはアルミニウムと珪素, Dグループの鉱物質には鉄が主に含有されていた。なお，Cグルー プの鉱物質には, アルミニウム, 珪素のほかにカルシウム, 鉄, ナ トリウム, カリウム，チタンなどを含むあのも認められた。光学顕 微鏡下で A, B , Dグループに属すると判断された鉱物質は, XMA の結果から単一鉱物よりなることが分かったが, Cグループ に属すると判断された鉱物質には微粒のAグループ鉱物質や他の鉱 物を含む場合むあった。

各石炭の低温灰化試料についてX線回折を行った結果1) では, い ずれの試料にも, 石英, カオリナイト, バッサナイト, 方解石のピー クが認められた。さらに, 大同炭には黄鉄鉱のピーク, Illinois炭 には黄鉄鉱とイライトのピーク, Battle River炭には斜プチロル沸 石のピークが認められた。また，低温灰化試料を用いて薄片を作成 し，A，Cグループの鉱物質について観察を行った。Aグループの 鉱物質は無色透明で直交ニコルにおける観察では単結晶粒の特徴を 示し, 一方Cグループの鉱物質は無色〜淡黄色を呈する微粒子の 集合体であった。

上述の顕微鏡観察とXMA の結果および低温灰化試料の X 線回 折結果から, 各グループの鉱物質について主に Aグループは石英, Bグループは黄鉄鉱, Cグループはカオリナイトなどの粘土鉱物か らなると結論づけられる。ただし, Cグループの鉱物質の場合, 数 種類の鉱物が混入していることもある。Dグループの鉱物質につい ては存在量が極微量のため, 同定は困難であったが, 鉄酸化鉱物と 考えられる。

\section{$4 \cdot 2$ 石炭および鉱物質の粒度分布}

Fig. 5 および Fig. 6 に, 6 炭種の石炭の-20 mesh試料について 石炭粒子および鉱物質の粒度分布測定を行った結果を示す。各石炭
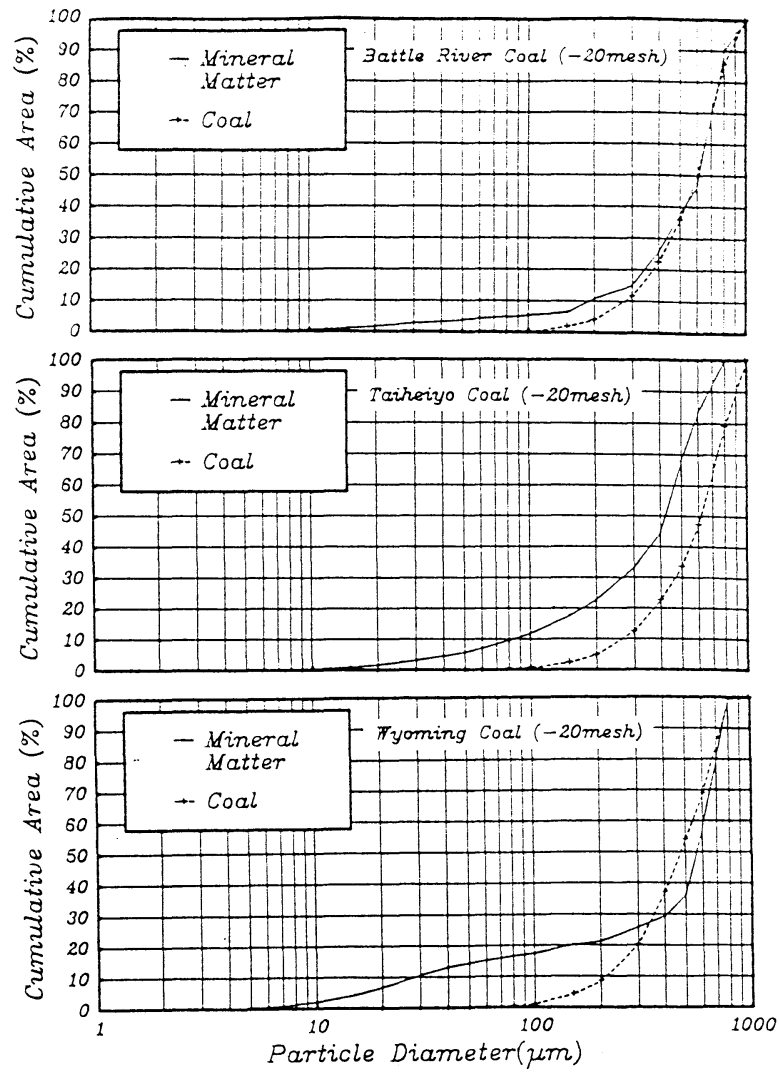

Fig. 6 Size distribution of coal and mineral matter in -20 mesh samples.

試料中の鉱物質の粒度分布の形は, Wandoan炭の場合を除き, い ずれも石炭粒子の粒度分布のそれと類似していた。両図に示した鉱 物質を 4 ・1で述べた鉱物質グループに分類し求めた粒度分布を Fig. 7 およびFig. 8 に示す。一般に, 最も細粒側に分布している のはAグループの鉱物質であり, 続いて B, C, Dグループの順に 粗粒側に分布する傾向が認められる。

Fig. 9 に, 大同炭, Illinois 炭, Wandoan炭の -200 mesh 試料 について石炭粒子および鉱物質の粒度分布を測定した結果を示す。 また, Fig. 10 に，各グループの鉱物質の粒度分布を示す。 -20 mesh 試料と比較して, -200 mesh 試料中の鉱物質の粒度分 布は, 石炭粒子の粉砕に伴い細粒側に移行した。特に, Cグループ の鉱物質はその粒度分布の移行が顕著であった。顕微鏡下での観察 では, A, B , Dグループの鉱物質は, Cグループの鉱物質に比べ 硬く, 石炭粒子中に存在する粗粒のあのは粉砕時にあまり粉砕され ないで石炭粒子から単体分離される傾向が認められた。一方, Cグ ループの鉱物質は, 石炭表面に薄く広がっている場合が多く, 石炭 粒子の粉砕時に石炭表面に付着したままの状態で粉砕され, 細粒化 していくあのが多かった。これらの現象は, 石炭と石英, 黄鉄鉱, カオリナイト等の粘土鉱物との硬度の違いに主に依存していると考 えられる。すなわち, 石英 (モース硬度 7.0 ), 黄鉄鉱 (モース硬度 $6 \sim 6.5$ ) は, 石炭 (モース硬度 2.5) より硬く, 顕微鏡下の観察結 果では石炭と明瞭な境界面をむっている。外部からそれらの粒子に 衝撃力が加わった際, その境界面で鉱物質粒子と有機質部分との剥 離が起きやすく, 石英, 黄鉄鉱は容易に単体分離される。一方, 力 オリナイト（モース硬度 2 ～2.5）が主体である粘土鉱物は, 粒度 が大きいにあかかわらず, 石炭とほぼ同じ硬さでかつ石炭と明瞭な 境界面をむたないため, 石炭とともに粉砕されやすく, 単体分離が 進行しにくい。このように, 石炭と石炭中の鉱物質との単体分離に は, 鉱物質の粒度のほかに, その硬度も密接に関係していると考え られる。 

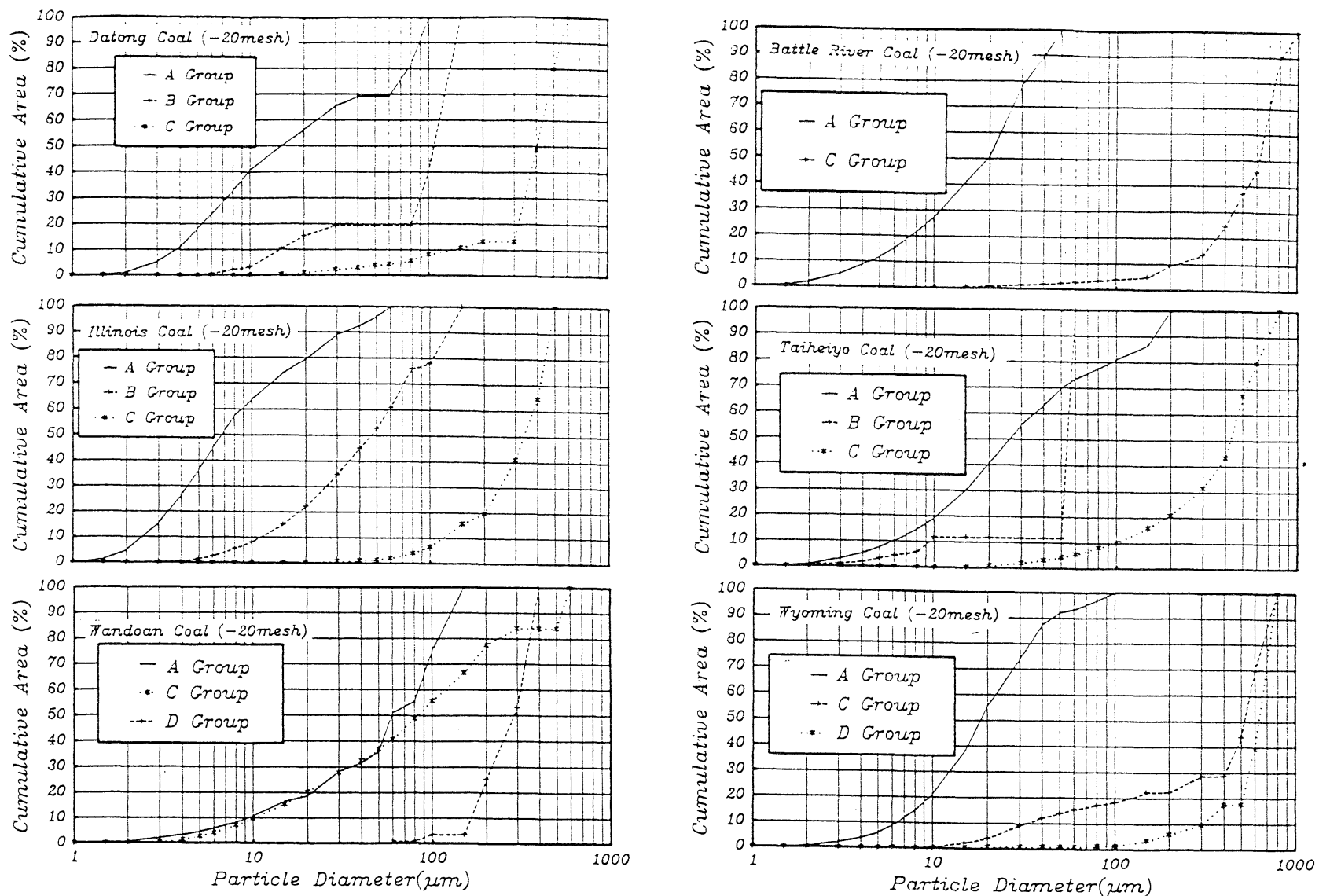

Fig. 7 Size distribution of each mineral in -20 mesh samples.

Fig. 8 Size distribution of each mineral in -20 mesh samples.
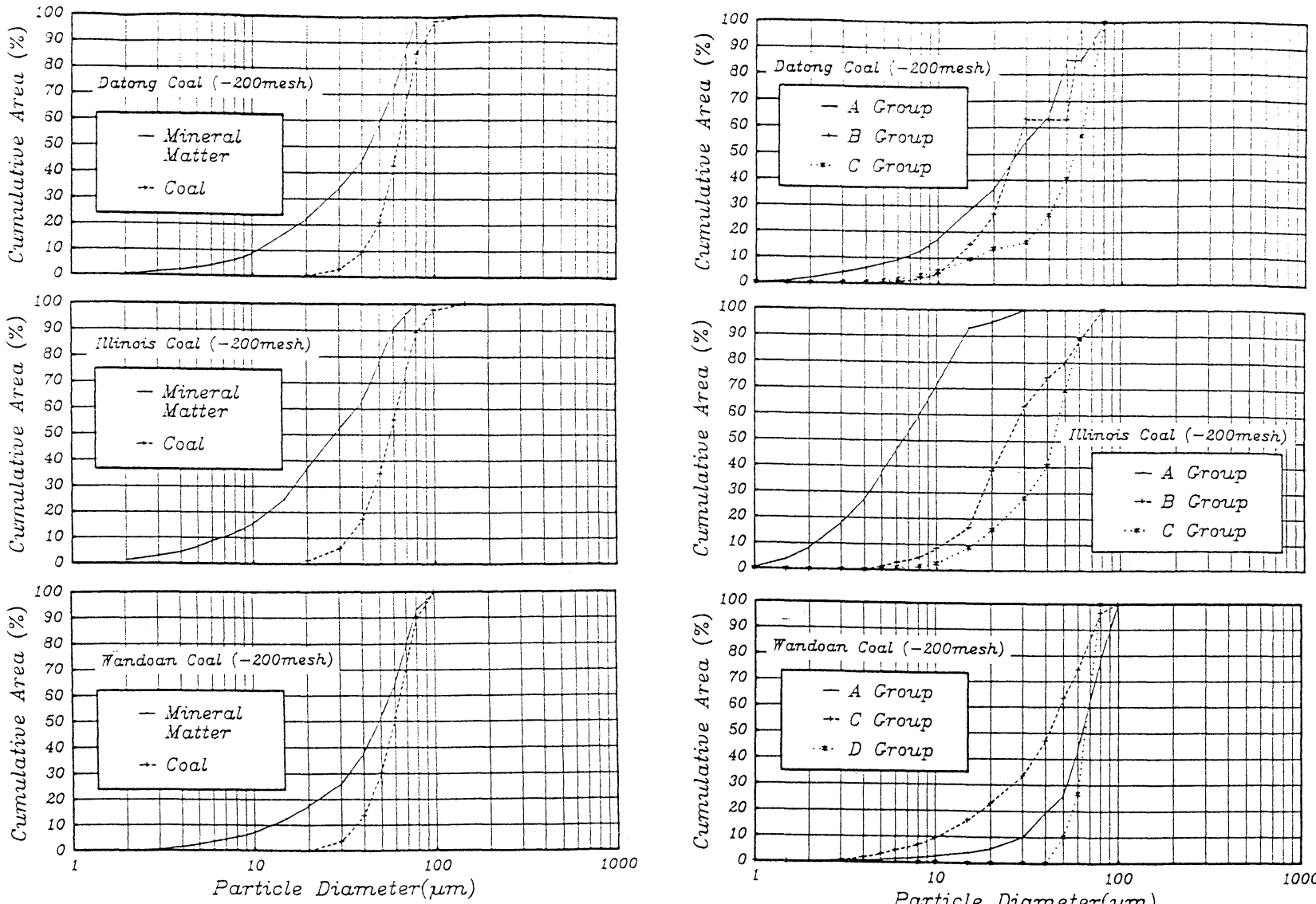

Fig. 9 Size distribution of coal and mineral matter in -200 mesh samples.

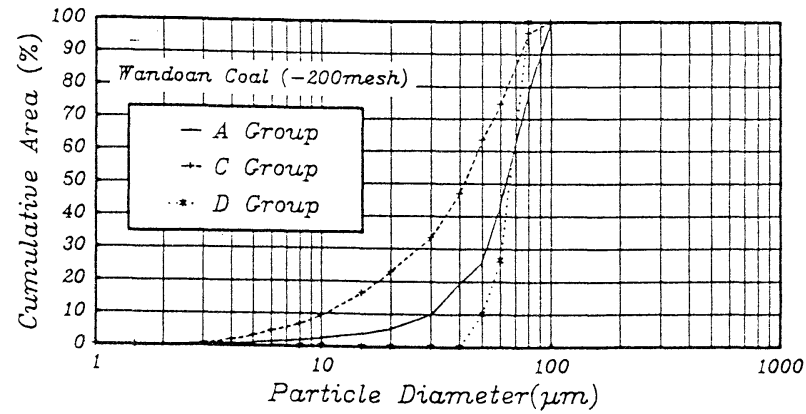

Fig. 10 Size distribution of each mineral in -200 mesh samples. 


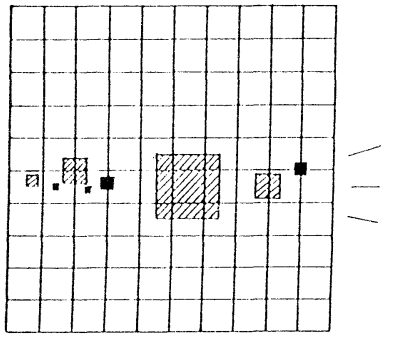

Fig. 11 Liberation model of minerals in coal.

\section{5. 鉱物質単体分離シミュレーション}

\section{$5 \cdot 1$ 鉱物質単体分離モデル}

上記の結果を基に，鉱物質の単体分離性について Fig. 11 に示す ような簡単なモデルを作成し， $\mathrm{A} ， \mathrm{~B}, \mathrm{C}, \mathrm{D}$ グループの単体分離 度の推算を行った。まず，次のように仮定した。

1) A， B，Dグループに属している鉱物質は, 石炭より硬く, 破 断線が入った場合, 石炭は粉砕されるが, 鉱物質粒子は粉砕されず 単体分離される。

2）Cグループに属している鉱物質に破断線が入った場合，鉱物 質は石炭と一緒に粉砕される。ただし，破断線に囲まれているCグ ループの鉱物質は, 単体分離される。

計算は，次のように行った。まず，上述の 6 炭種の -20 mesh 試 料についての測定結果を基に石炭粒子および鉱物質の粒径，個数を 定め,これから石炭試料の総面積を求めた。この面積を有する正方 形を Fig. 11のように定めた（図において最大の正方形）。次に, 乱 数を発生させ, 各鉱物質粒子の位置を決定する。各鉱物質粒子の位 置は, 縦, 横それぞれの石炭の辺の長さにコンピュータにより発生 させた 0〜 間の 7 桁の乱数を掛け合わせることにより定めた。た だし，鉱物質粒子の一部がこの石炭片からはみ出した場合，再度計 算を繰り返し位置を決定した。間隔 $L(\mu \mathrm{m})$ で破断線を入れ，1） と 2 ）の仮定に基づき, 単体分離した各鉱物質の面積を求める。各 鉱物質の単体分離度は単体分離した鉱物質の面積を鉱物質粒子の総 面積で除することにより求める。上記の計算を間隔 $L$ を順次 $1 \mu \mathrm{m}$ ずつ狭めて, 繰り返し行う。 $L$ は, 均一に粉砕された石炭粒子の一 辺の長さを示していることから, 以後 $L$ を石炭の粒子径として表 示する。

$5 \cdot 2$ 単体分離シミュレーション

石炭を粉砕することにより鉱物質の単体分離が進行する過程を, 上述の鉱物質単体分離モデルを用いて計算した。なお， $L$ の初期值 は $100 \mu \mathrm{m}$ とした。各炭種について得られた石炭粒子径と面積基準 単体分離度との関係 (以後, この関係を示す曲線を単体分離度曲線 と呼ぶ）をFig. 12 およびFig. 13 に示す。なお，それぞれの曲線 は, 整式で表されるとして最小 2 乗法により求めた。これらの図よ り, 石炭粒子の粒子径が小さくなるに従い, いずれの鉱物質も単体 分離度が大きくなってゆくことが分かる。これは, 粉砕の進行にっ れ各グループの鉱物質の単体分離が進んでいることを示している。 単体分離度曲線は, それぞれの石炭によって特徽的な変化を示して

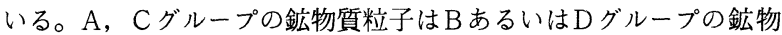
質粒子に比べ，50\%単体分離度粒子径が小さく，A，Cグループの 鉱物質は比較的細かい粒度で単体分離が促進されることが理解され る。これは，Aグループの鉱物質の粒度が B，Dグループに比べ小 さいことと，Cグループの鉱物質の粒度は比較的大きいが，硬度が B，Dグループに比べ小さく石炭とともに粉砕されるため，単体分 離が起こりにくいという本単体分離モデルの特徴とによる。

石炭を -200 mesh に粉砕した場合の各鉱物質の単体分離度を石
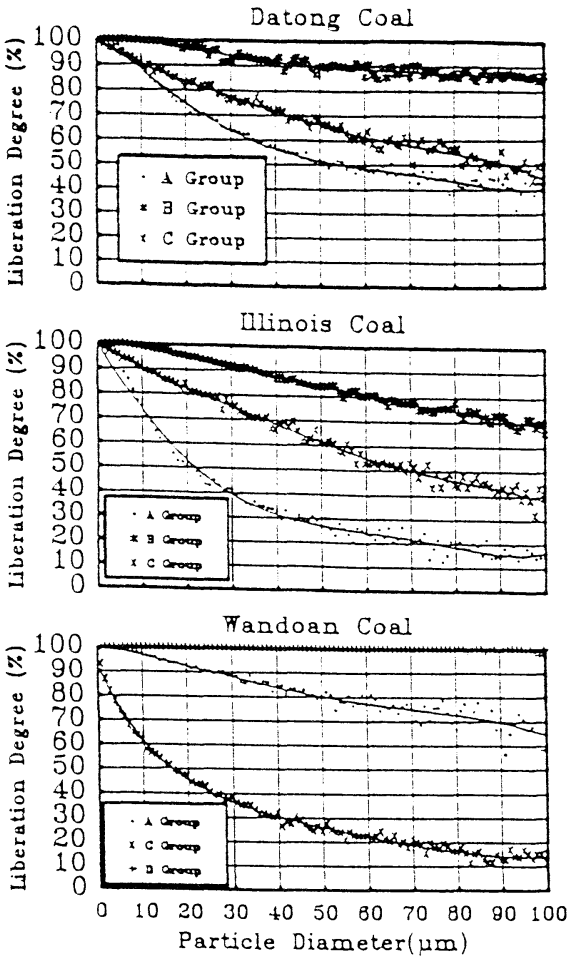

Fig. 12 Calculation results of liberation degree.

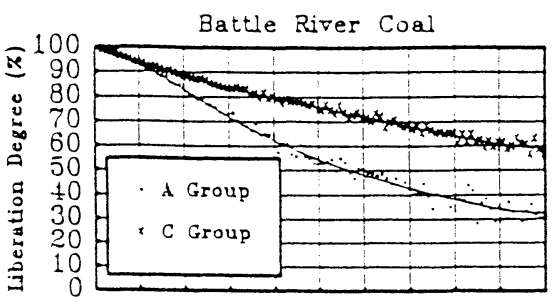

Taibeigo Coal
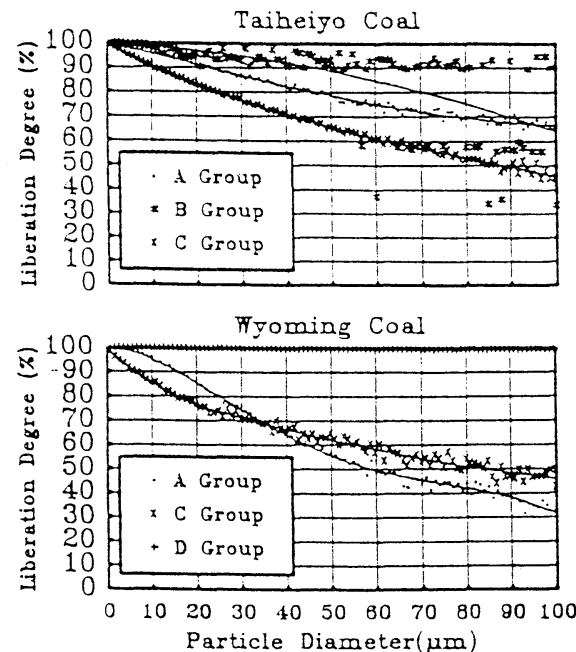

Fig. 13 Calculation results of liberation degree.

炭試料の粒度分布および Fig. 12，Fig. 13 の単体分離度曲線を基に 計算した。計算は次式により行った。

単体分離度 $=\Sigma A(d) \times L(d)$

ここで,

$d:$ 石炭粒子の粒子径 $(\mu \mathrm{m})$

$A(d)$ : 粒子径が $d$ なる石炭粒子の面積割合 (一)

$L(d)$ : 石炭を粒子径 $d$ に粉砕した際の各グループの鉱物質の単体 分離度 $(\%)$ 
Table 1 Liberation degree of each mineral group in -200 mesh samples (\%)

\begin{tabular}{c|rr|rr|rr|rr}
\multirow{2}{*}{ Mineral } & \multicolumn{2}{|c|}{ A Group } & \multicolumn{2}{c|}{ B Group } & \multicolumn{2}{c|}{ C Group } & \multicolumn{2}{c}{ D Group } \\
\cline { 2 - 10 } Sample & Exp. & Cal. & Exp. & Cal. & Exp. & Cal. & Exp. & Cal. \\
\hline Datong & 64.8 & 51.1 & 90.5 & 89.4 & 51.3 & 64.0 & - & - \\
\hline Illinois & 20.1 & 29.2 & 66.3 & 83.9 & 21.3 & 61.9 & - & - \\
\hline Wandoan & 86.1 & 79.5 & - & - & 31.5 & 25.5 & 99.8 & 99.9 \\
\hline
\end{tabular}

Exp.: Experimental value

Cal. : Calculated value

- : Not observed and calculated

-200 mesh 試料について得られた各鉱物質の単体分離度の計算 結果と測定結果を Table 1 に示す。Illinois炭のCグループ鉱物質 の結果を除くと, 計算値と実測值との差は10数\%以内であり, 両者 は比較的よく一致した。前述したようにCグループの鉱物質は，石 炭表面に薄く広がっている場合が多く, 顕微鏡下での単体分離度の 測定精度が他の鉱物に比べ低いと考えられ，これが Illinois炭にお けるCグループの差に現れたものと推察される。単体分離度の測定 法等については今後さらに検討を要するが, 上記の鉱物質単体分離 モデルを用いて，石炭中の各鉱物質の単体分離性をおおよそ把握す ることができる。

\section{6.まと め}

本研究では, まず, 6 炭種の石炭試料について, 顕微鏡観察を行 い，石炭中の鉱物質を外観の性状により A， B， C，Dの四つのク ループに分類した。この顕微鏡観察の結果とX線マイクロアナライ ザによる元素分析結果, 低温灰化試料のX線回折結果から, 各グルー プに属する鉱物質について, 主にAグループは石英，Bグループは 黄鉄鉱，Cグループはカオリナイトなどの粘土鉱物，Dグループは 鉄酸化鉱物であることを明らかにした。

次に, 6 炭種の -20 mesh 試料について石炭粒子および各グルー プの鉱物質の粒度分布を測定した。いずれの試料も最も細粒側に分 布しているのはAグループであり， B， C，Dグループの順に粗粒
側に分布する傾向があった。大同炭, Illinois 炭, Wandoan 炭の - 200 mesh 試料について同様に粒度分布測定を行った。これらの 試料の粒度分布測定結果抢よび顕微鏡下での観察結果から, A, B, Dグループの鉱物質は，Cグループの鉱物質に比べ硬く，石炭粒子 中に存在する粗粒のむのは粉砕時にあまり粉砕されないで石炭粒子 から単体分離されるが，Cグループの鉱物質は，石炭表面に薄く広 がっている場合が多く, 石炭粒子の粉研時に石炭表面に付着したま まの状態で粉砕され細粒化していくことが分かった。

これらの結果を基に，鉣物質の粒度および硬度を考慮した鉱物質 単体分離モデルを作成し, シミュレーションにより, 石炭の粉砕粒 度と各鉱物質の単体分離度との関係について調べた。各グループの 鉱物質の単体分離度曲線はそれぞれの石炭によって特徽的な変化を 示した。単体分離度の計算值と実測值とは，比較的よく一致してお り, 本研究で提案した鉱物質単体分離モデルを用いて石炭中の各鉱 物質の単体分離性をおおよそ把握することができた。

なお，本研究費の一部は，平成 3,4 年度文部省科学研究費補助 金 (一般研究 (C) , 研究課題番号：03650508）によったことを付 記し謝意を表する。

\section{引用 文 献}

1）平島剛・王 楠・恒川昌美: 資源と素材, Vol. 110, p. 461-466, (1994)

2) Bomberger, D. R. and Duel, M. : Trans. of SME/AIME, Vol. 229, p.65-69, (1964)

3) Vleeskens, J. W., et al:: Fuel, Vol. 64, p. $342-347$, (1985)

4) Irdi, G. A. and Rohar, P. C. : US DOE Report, CONF - 8609178-1, (1986)

5) Harvey R. D. and DeMaris, P. J. : Org. Geochem., Vol. 11, p. 343-349, (1987)

6) Mazumdar, M., Carlton, R. W. and Irdi, G. A. : Int. J. of Coal Geol., Vol. 9, p. $371-383,(1988)$

7) Morsi, B. I., Venkatadri, R., Chiang, S. H., et al. : US DOE Report, DOE/ $\mathrm{PC} / 88877 / \mathrm{T} 1,(1989)$

8) Mazumdar, M. and Irdi, G. A. : Fuel, Vol. 68, p. 870-875, (1989)

9）原田種臣・大和田秀二 ・大木達也 -小野寺次郎 : 資源と素材, Vol. 105, p. 870875, (1989) 